HABITAT, 28 (3), 2017, 106-113

DOI: 10.21776/ub.habitat.2017.028.3.15

\title{
Analysis of Strawberry Farmer's Satisfaction for Utilization of " $X$ " Fungicide in Pandanrejo Village, Batu City
}

\author{
Baskoro Aji Prihatmojo ${ }^{1 *}$, Ratya Anindita ${ }^{2}$ \\ Socio-Economics Department, Faculty of Agriculture, University of Brawijaya, Jl. Veteran, Malang \\ 65145, Indonesia
}

Received: 31 July 2017; Revised: 23 November 2017; Accepted: 1 December 2017

\begin{abstract}
The objective of this research are to understand some factors that are affecting strawberry farmers satisfaction in utilization of "X" fungicide and the level of farmer satisfaction. The location of this research in Pandanrejo Village, Batu City with 50 respndents. The method which was used in this research are decriptive statistics, Logistic Regression, and Customer Satisfaction Index (CSI). Measuring factors that affect satisfaction used four dummy variables, such as education level, group refference, training experience, and information source. And then to measure the level of satisfaction used variable of product attributes such as variety of product size, composition, expire date, procedure, permite of distribution, product availability, benefit, product information, completeness, rate of extermination, and price. The result of logistic regression that group reference and source information are affecting the satisfaction of strawberry farmer. The obtained result of Customer Satisfaction Index method got 73,43\% which means that strawberry farmer are satisfied with fungicide " $X$ ".
\end{abstract}

Keywords: farmers satisfaction; logistic regression; Customer Satisfaction Index

How to cite:

Prihatmojo, B. A., \& Anindita, R. (2017). Analysis of Strawberry Farmer's Satisfaction for Utilization of " X " Fungicide in Pandanrejo Village , Batu City. HABITAT, 28(3), 106-113. https://doi.org/10.21776/ub.habitat.2017.028.3.15

\section{Introduction}

Strawberry which previously was an elite fruit is currently easily to be found in some domestic markets (Hanif \& Ashari, 2012). Strawberry is a fruit which originated from subtropical climate and can only grow in the area which has low temperature such as in highlands. Java island has high amount of strawberry production in Indonesia. This fact is supported by the data which was obtained from (BPS-Statistics Indonesia, 2016), which describes that in 2014, West Java province redounded national production with amount of 28,380 tones. While, East Java province were stood in fourth rank, right after Middle Java and Bali with the amount of production in 2014 until 567 tones and became 710 tones in 2015 .

*Corresponding author

E-mail: baskoroajip@gmail.com

Telp: +62-819-38225768
The highest strawberry production in Indonesia happened in 2012 with amount of production 169,976 tones and afterwards it decreased steadily in the next following year and it reached 31,801 tones in 2016. This can be caused by several problems in strawberry bussiness some problems which usually occur in strawberry bussiness is deficiency of qualified seed's availibilities, pest attacks and also diseases. One of strawberry plant's disease is caused by fungi.

The treatment that farmers usually undergo is by using pesticides to control the fungi and virus which harm plants. Heretofore, pesticides are also used to exterminat several pest attacks and diseases. Pesticides are divided in two groups which are organic pesticides and inorganic pesticides. According to (Mustikarini, Retnaningsih, \& Simanjutak, 2014), most of farmers which use inorganic pesticides to control pests and plant diseases. This is due to trust of the farmers with the results of inorganic perpticides

Available online at HABITAT website: http://www.habitat.ub.ac.id

ISSN: 0853-5167 (p); 2338-2007 (e) 
performance so that inorganic pesticides become the priority to be used.

Sort of pesticides are divided according to their targets. One of pesticides type is fungicides. Fungicides is utilized to control the fungi that attack cultivated plants. Type of fungicide that is familiar in Indonesia is " $\mathrm{X}$ ". " $\mathrm{X}$ " has for long time distributed in Indonesia since 1970s and still being used continuously until now. A brand of pesticide that has been utilized by the farmers for a long period can cause the emergence of habitual factor and the farmers has understood the performance of that pesticides to control pests and diseases. It means that farmers are satisfied towards that brand of pesticides (Mustikarini, Retnaningsih, \& Simanjutak, 2014).

The satisfaction of the farmers can be emerged after they utilized that product. Further steps after consumption process is alternative evaluation post-purchasing or post-consumption whereas the result of this process is that consumer is satisfied or not towards the product (Sumarwan, 2014). The satisfaction will lead comsumer to buy and consume that product repititively. Every farmer has a knowledge about the value of the product in one particular brand (Peter and Olson, 2013). Understanding of the product consist of awareness towards categories and product's brands, product attributes and confidence of product attributes generally. Product attributes are attached in the product which is utilized or consumed (Engel, Blackwell \& Miniard, 1990).

The farmers utilize fungicide " $\mathrm{X}$ " according to several supporting factor such as copatibility of product performance to farmers's expectation. It is related to (Kotler and Keller, 2009) which stated that the satisfaction of consumer will be emerged if the product performance is suited to what consumer expect. Besides, the satisfaction can ben also arised if the hope is in accordance with expectation. This expectation can be originated from the personal, friend or family experiences, information from media such as printed or electronic media or other sources (Kotler \& Keller, 2009). In other words, environment can affect the consumer's expectation.

Strawberry farmers in Pandanrejo Village has for long period utilized fungicide " $\mathrm{X}$ " to control fungi in strawberry plant. Moreover, they has been used that fungicide since 1970s. So that, there is a probability that strawberyy farmers feel satisfied towards the performance of fungicide "X". In addition, factor that affect the strawberry farmers's satisfaction in utilization of " $X$ " fungicide can be derivated from environment around the farmers. So that, the examination related to the strawberry farmers satisfaction in Pandanrejo Village in utilizing " $\mathrm{X}$ " fungicide is interesting to be futher investigated.

Study about farmers satisfaction has been ever conducted by (Wicaksana, Muhaimin \& Koestiono, 2013); (Mustikarini, Retnaningsih, \& Simanjutak, 2014); (Sarmin \& Widajanti, 2013); (Luo \& Timothy, 2016); (Aydogdu, Yenigun \& Aydogdu, 2015). Those work has analyzed several factors that affect farmers satisfaction in agriculture field such as drugs, irrigation and agricultural program. Moreover, it were also explained that how to analyze the level of farmers satisfaction using several methods.

By developing several previous studies and observation of actual phenomena in the field of study, the objectives of this research can be determined such as to investigate how far strawberry farmers recognize " $\mathrm{X}$ " fungicides. The second objectives is to observe factors that affect strawberyy farmers satisfaction in utilizing " $X$ " fungicide. And the last is to analyze the level of strawberry farmers satisfaction in utilizing " $X$ " fungicide.

\section{Research Methodology}

This research was conducted in Pandanrejo Village, Bumiaji Districs, Batu City. Selection of this place refered to the fact that Pandanrejo village is the center of strawberry production in Batu city. This research was performed in May 2017. Type of data that is utilized is primary data in the form of structured interview and secondary data which originated from BPS-Statistics Indonesia related to the strawberry production and Pandanrejo village office related to inhabitant distribution. Methods of determining sample used simple random sampling. The number of used respondent is 50 persons. Determination of respondents number refered to the model (Lemeshow, Hoshmer, Klar \& Lwanga, 1995) :

$$
n=\frac{z^{2} P(1-P) N}{d^{2}(N-1)+z^{2} P(1-P)} \text {. }
$$

The attribute variable is chosen according to (Mustikarini, Retnaningsih, \& Simanjutak, 2014). This instrument are tested with validity test and reliability test. Validity test explained 
that all of variables are valid except completeness. But, this attribute will be used because of to support the data. For the reliability test, Cronbach's alpha got 0.721 .

\subsection{Analysis of Descriptive Statistics}

Descriptive statistics is utilized for explaining the respondents characteristics and product knowledge of " $\mathrm{X}$ " fungicide. Product knowledge can be used to discover how far strawberyy farmers understand bout " $X$ " fungicide. This knowledge can measure how far farmers can acquaint the " $\mathrm{X}$ " fungicide. According to (Sumarwan, 2014) that product knowledge consist of some kind of information product. Product information involves product brand, advantages, purchasing location, utilization method, attribute or product characteristic, general product's trust.

\subsection{Analysis of Logistic Regression}

Logistic regression is utilized for discovering factors that affect farmers satisfaction. Analysis of logistic regression is analysis tool that is used to describe the relation between dependent variables which has two or more categories with one or more independent variables (Hendayana, 2013). Hypothesis test was conducted in several testing method as follows: (Hendayana, 2013)

1. Model Significance Test (G Test)

$\mathrm{G}$ Test is utilized for discovering whether the independent variable can affect dependent varibale. Formula of $\mathrm{G}$ Test and Hypothesis that is used as follows :

$$
\begin{aligned}
& G=-2 \ln \left[\frac{L_{0}}{L_{1}}\right] \text {. } \\
& H_{0}: \beta_{i}=0 \\
& H_{1}: \beta_{i} \neq 0 \\
& \text { Where : } \\
& \mathrm{G}=\text { Maximum Probability Ratio (likelihood } \\
& \text { ratio test) } \\
& L_{0}=\text { Likelihood without } \\
& \text { explained/independent variable (model } \\
& \text { only from the contant } \\
& L_{1}=\text { Likelihood } \text { with all explained variable } \\
& i=1,2,3, \ldots \ldots, \mathrm{n} \\
& \mathrm{G} \text { value follows the distribution of chi- } \\
& \text { square }\left(\mathrm{X}^{2}\right) \text { with degree of freedom } p \text {. The }
\end{aligned}
$$

least one independent variable which affect the dependent variable.

\section{Goodness of Fit Test}

This test is utilized for examining the suitability between input data in the model and observed data. Method which is used to test appropriateness of the model using HosmerLemeshow Test. Hosmer-Lemeshow Test equation can be described as:

$$
\hat{\mathrm{C}}=\sum_{k=1}^{g} \frac{\left(O_{k}-n^{\prime}{ }_{k} \bar{\pi}_{k}\right)^{2}}{n^{\prime}{ }_{k} \bar{\pi}_{k}\left(1-\bar{\pi}_{k}\right)}
$$

$\mathrm{H}_{0}$ : There is no significant difference between model and observed data

$\mathrm{H}_{\mathrm{a}}$ : There is a significant difference between model and observed data

Where:

$\hat{\mathrm{C}}$ : Value of Hosmer-Lemeshow Test

$g$ : Number of group

$n^{\prime}{ }_{k}$ : Total of observation in group $-k$

$O_{k}$ : Total Y value in group $-k$

$\bar{\pi}_{k}$ : Average from $\hat{\pi}$ to group $-k$

Hosmer-Lemeshow Test was conducted according to chi-square distribution with degree of freedom $\mathrm{g}-2\left(\mathrm{X}_{(\mathrm{g}-2)}^{2}\right)$. The decision rule which is used is rejecting $\mathrm{H}_{0}$ if calculated $\mathrm{X}^{2}>\mathrm{X}_{(\mathrm{g}-2)}^{2}$ in the level of confidence $95 \%$. When $H_{0}$ is rejected, it means that model can not be accepted because there is a significant difference between model and observed data.

\section{Partial Parameter Test (Wald Test)}

Wald test is utilized for examining the parameter $\beta_{i}$ partially. In linear regression, Wald test is identical with T test. This test is performed by comparing value of maximul likelihood estimation from parameter coefficient $\left(\widehat{\beta}_{\mathrm{i}}\right)$ with value of standard error estimation $\beta_{\mathrm{i}}$. Formula of Wald test can be shown as follows :

$$
\begin{aligned}
& W=\frac{\widehat{\beta}_{i}}{S E\left(\widehat{\beta}_{i}\right)} \\
& \mathrm{H}_{0} \quad: \beta_{\mathrm{i}}=0 \\
& \mathrm{H}_{\mathrm{a}}: \beta_{\mathrm{i}} \neq 0 \\
& \text { where: } \\
& \text { W : Result of Wald test } \\
& \hat{\beta}_{i} \quad \text { : Value of estimation } \beta_{\mathrm{i}} \\
& \text { SE }\left(\widehat{\beta}_{\mathrm{i}}\right) \quad \text { : Value of standard error } \beta_{\mathrm{i}} \\
& i \quad: 1,2,3, \ldots, \mathrm{n}
\end{aligned}
$$

Wald test follow standar normal distribution with decision rule is that $\mathrm{H}_{0}$ will be rejected if $\left|W_{\text {hitung }}\right|>Z_{\frac{\alpha}{2}}$ with level of confidence $95 \%$. When $\mathrm{H}_{0}$ is rejected, it means that parameter is significant with significance value $\alpha=0,05$ so 
that partial independent variable affect dependent variable.

\section{Marginal effect}

Marginal effect in this reseach is an alteration of probability in strawberry farmers satisfaction towards usage of " $\mathrm{X}$ " fungicide as a result of changes in one independent variable unit which are training experience, education level, group references and information sources. Margical effect can be calculated according to this following equation (Williams, 2017):

$M E X_{i}=P(Y=1 \mid X) * P(Y=0 \mid X) * b_{i}$ where :

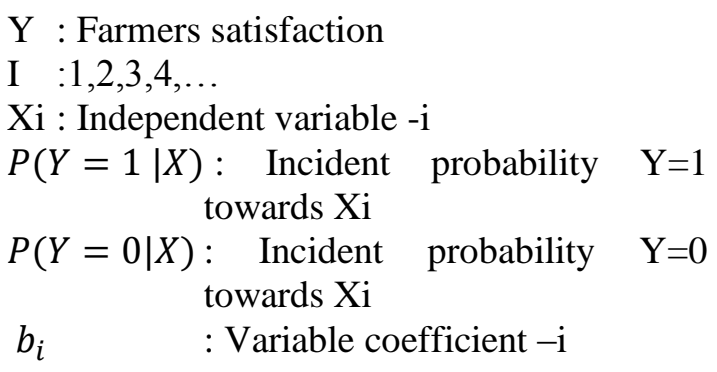

\subsection{Analysis of Customer Satisfaction Index}

In measurement of consumer satisfaction level using Customer Satisfaction Index (CSI) method, there is four basic calculation as follows:

1. Determining Mean Importance Score (MIS) and Mean Satisfication Score (MSS).

$M I S=\frac{\sum_{i=I}^{n} Y i}{n}$.
$M S S=\frac{\sum_{i=I}^{n} x i}{n}$

where :

Yi $=$ Value of attribute's importance $-\mathrm{i}$

$\mathrm{Xi}=$ Value of Attribute; s performance $-\mathrm{i}$

I = Attribute 1, attribute 2, attribute 3, attribute $4, \ldots$., attribute $x$ (adjusted to the number of research variable)

$\mathrm{n} \quad=$ Number of respondents

2. Constructing Weight Factors (WF) which is percentage weight of MIS value for each attributes towards total MIS in all attributes

$$
W F I=\frac{M I S i}{\sum_{i=I}^{p} \text { MISi }} 100 \% \text {. }
$$

where :

I = Attribute 1, attribute 2, attribute 3, attribute $4, \ldots$, attribute $\mathrm{x}$ (adjusted to the number of research variable)

$\mathrm{p}=$ Number of attributes
3. Creating Weight Score (WS) which is multiplication between Weight Factors (WF) and Mean Satisfication Score (MSS).

$W S i=W F i \times M S S i$

4. Determining the value of Customer Satisfication Index (CSI) by calculating Weight Total (WT), is total from all entirely value of Weighted Score (WS). Subsequently, calculating the consumer satisfaction index which is calcukation from Weight Total (WT) divided by maximum scale, then multiply by $100 \%$.

$$
C S I=\frac{W T}{5 Y} \times 100 \% \text {. }
$$

where: $5 \mathrm{y}=$ maximum scale

\section{Result and Discussion}

\subsection{The condition of Strawberry Plantation in Pandanrejo Village}

Strawberry production in Pandanrejo Village peaked in 2015. In this year, it can produce until 20 tons/ha. Some farmers said that in the 2015, strawberries in Pandanrejo Village were abundant in which they can harvest 2 times a day. Moreover, some farmers who have land more than $2500 \mathrm{~m}^{2}$ can arrange a harvest schedule everyday. Strawberry picking recreation has a high visitation number in 2015. In the 2016, the production of strawberry declined gradually. Many farmers got a financial loss because strawberry plants has severely damaged $80 \%$ until $90 \%$. It caused by the extreme weather which could make strawberry plant are severely damaged. Lots of farmer complained because many strawberry plant experienced a harvest failure and the farmers have to replanting their cultivation again. This extreme weather caused by instability between rainy season and dry season in 2016. According to some farmers, rainy season has a longer period than usual and conversely the dry season has a shorter period so that it caused the strawberry plant could not be tough enough to encounter this type of season. In the rainy season, strawberry plants had been considerably damaged by fungi on their leaves (leaf spot) and led to dried leaved and became died.

Strawberry commodities in Pandanrejo Village starting to encounter a development in 2017 and it is the proper time to replant some strawberry plants in the Pandanrejo Village. Between April until May 2017, the farmers began 
replantation in some strawberry plant and decided to use new seeds. In June 2017, some of the strawberry farmers began to enjoy their harvest. However, the strawberry yield is still low just about $10 \mathrm{~kg} /$ week with selling price $\mathrm{Rp}$ $35,000 / \mathrm{kg}$. The condition of strawberry farms which have started to develop in Pandanrejo Village are expected able to restore this village to become center of strawberry commodities in Batu City.

\subsection{Product Knowledge of Fungicide " $X$ "}

In this research, product knowledge included some information of fungicide type, benefit, procedure, dosage, time and safety that can be seen in Table 1. And then, it was also explained that the usage duration of fungicide " $\mathrm{X}$ " which is correlated to the satisfaction in utilizing fungicide " $X$ ".

Tabel 1. Farmer Knowledge of Product dalam in Utilizing " $X$ " Fungicide

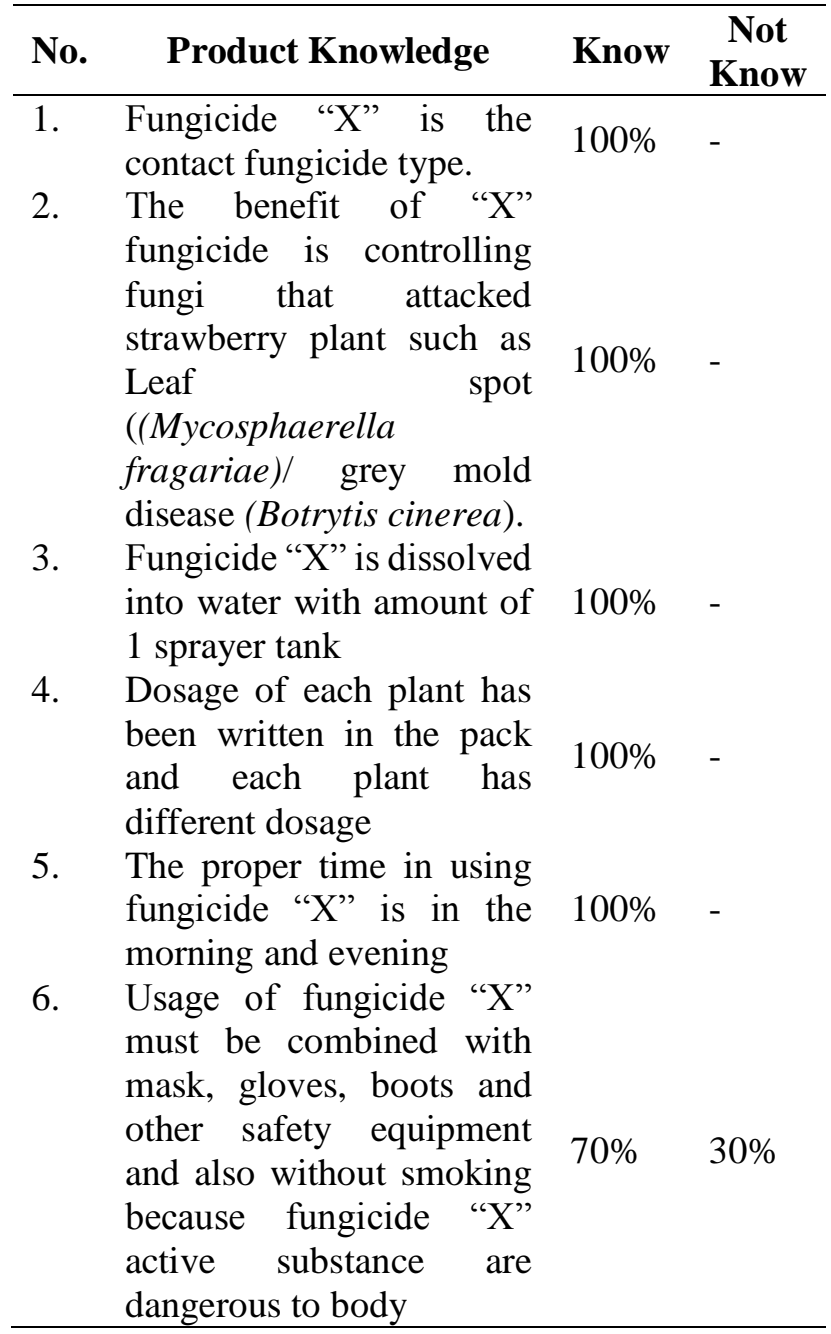

Product knowledge is also related to the level of product's usage duration. The level of product's usage duration of fungicide " $X$ " by respondents are varied. The level of usage duration is divided into two categories that are using less than 10 years and more that 10 years. Distribution of respondents can be seen in the Table 2.

The majority of respondents utilize " $X$ " fungicide until now. According to Table 2 that $82 \%$ farmers utilize " $\mathrm{X}$ " fungicide more than 10 years. $68 \%$ farmers or 34 farmers are still use " $\mathrm{X}$ " fungicide in the strawberry plantation. The rest of $32 \%$ farmers seldom use the fungicide anymore because of some reasons. Based on the interview's result, farmers decided to use " $X$ " fungicide infrequently because of expensive price and it was not proportional with their income from harvest. (Mustikarini et al., 2014) stated that pesticides brand which is used in long period time can cause some habitual factors. Likewise, farmers have known about performance of pesticides to control the disease and pest. It was indicated that farmers felt satisfied with the brand of pesticides. Hence, strawberry farmers are possibly satisfied in utilizing " $X$ " fungicide.

Tabel 2. Distribution of Respondent according to the usage period of Fungicide " $\mathrm{X}$ "

\begin{tabular}{lc}
\hline Usage Period & Percentage (\%) \\
\hline Less than 10 years & 18 \\
More than 10 years & 82 \\
\hline TOTAL & $\mathbf{1 0 0}$ \\
\hline 3.3. Factors that Affect & Satisfaction of \\
Strawberry Farmer &
\end{tabular}

The result of logistic regression in the Table 3 shows that independent variables give significant influence to the model. In other words, it can be stated fit (Chi-square $=17,833, \mathrm{df}=4$, $\mathrm{p}<0,05)$. Besides, Chi-square significance in the Hosmer and Lemeshow test is more than 0,05 $((p>0,05)$. It means that this model can be accepted and being used in the hypothesis test with the success estimation score 77 percentage. The obtained score of Negelkerke R Square is 0,440 . It means that this model just explains $44 \%$ and the rest will be explained by other variables beyond this model.

Group reference variable and information source give significant effect to the satisfaction of strawberry famers. The obatined marginal effect from group reference variable is 0,3596 . It means 
that strawberry farmers who have group reference to the family tend to increase their satisfaction 0,3596 times. In this research, family becomes important part in the plantation. The majority of respondent learn from their family and have been grown in the agriculture environment. According to (Mustikarini, 2014) that family affects a farmer to utilize some brand pesticides because they have known that pesticide from their family. In addition, in this research farmers who are became respondent have been married and have children. According to (Sumarwan, 2014) that family has great impact because family member will reciprocally suggest the other member to make a decision in buying or using some product. So that, family is became a group that affect satisfaction of farmer to utilize some particular product's brand.

Tabel 3. The Result of Logistic Regression in Some Factors that Affect Strawberry Farmers in Utilizing " $\mathrm{X}$ " Fungicide

\begin{tabular}{|c|c|c|}
\hline Variable & Sig. & $\begin{array}{c}\text { Marginal } \\
\text { Effect }\end{array}$ \\
\hline \multicolumn{3}{|l|}{ Training } \\
\hline $\begin{array}{l}\text { Experience } \\
\text { (EXP) }\end{array}$ & 0,746 & $-0,456$ \\
\hline $\begin{array}{l}\text { Education Level } \\
\text { (EDU) }\end{array}$ & 0,957 & 0,008 \\
\hline $\begin{array}{l}\text { Group Reference } \\
(\mathrm{GR}) * *)\end{array}$ & 0,017 & 0,3596 \\
\hline $\begin{array}{l}\text { Information } \\
\text { Source (SO)**) }\end{array}$ & 0,020 & 0,347 \\
\hline Constant & 0,451 & - \\
\hline \multicolumn{2}{|c|}{ Negelkerke $R^{2}$} & 0,440 \\
\hline \multicolumn{3}{|c|}{ **) Significant in the $\alpha=5 \%$} \\
\hline \multicolumn{3}{|c|}{$\begin{array}{l}\text { Information source that come from friends } \\
\text { also significanlly affect to the satisfaction of } \\
\text { strawberry farmers. The marginal effect of this } \\
\text { variable is 0,347. It means that strawberry } \\
\text { farmers who get some information from friend } \\
\text { tend to uplift the satisfaction } 0,347 \text { times. It } \\
\text { caused by many farmers in this research took } \\
\text { some information about agriculture from their } \\
\text { friends. As social creature, farmers kept in touch } \\
\text { with their friends and the society in their village } \\
\text { are very close. Friends is a place for them to } \\
\text { gather and exchange their opinions. According to } \\
\text { (Sumarwan, 2014), opinion and experience from } \\
\text { friends are sometimes affect decision making of } \\
\text { consumer in utilizing some products. If a friend } \\
\text { feels satisfied with the product, he will tell to }\end{array}$} \\
\hline
\end{tabular}

other about that product. Farmers will think to use that product because of the friend information.

\subsection{Customer Satisfaction Index (CSI)}

The result of CSI explains that price and expiration date have low Weight Score (WS). According to the research's result, strawberry farmers give low score to those attributes. Price attribute is caused by the fungicide " $\mathrm{X}$ " price that unreachable for farmers. And then expire date attribute in the " $\mathrm{X}$ " fungicide isn't explained clearly in the product. Customer Satisfaction Analysis (CSI) can be seen in the Table 4.

According to the Table 4, it can be explained that the score of Customer Satisfaction Index is $73.04 \%$. It means that farmers are satisfied with the level of score $73.04 \%$. That score is more than $50 \%$ and explains that farmers feel satisfied. The conclusion, strawberry farmers in the Pandanrejo village are satisfied with the performance and importance of those fungicide "X" attributes.

Table 4. Calculation of Customer Satisfaction Index (CSI)

\begin{tabular}{|c|c|c|}
\hline No & Product Attributes & $\begin{array}{l}\text { Weight } \\
\text { Score }(W S)\end{array}$ \\
\hline 1. & Variety of product Size (p1) & 0,2826 \\
\hline 2. & Composition (p2) & 0,3848 \\
\hline 3. & Expire Date (p3) & 0,1431 \\
\hline 4. & Procedure (p4) & 0,4181 \\
\hline 5. & Permite of Distribution (p5) & 0,3847 \\
\hline 6. & Product Availibility (p6) & 0,4203 \\
\hline 7. & Benefit (p7) & 0,422 \\
\hline 8. & Product Information (p8) & 0,3725 \\
\hline 9. & Completeness (p9) & 0,3217 \\
\hline 10. & $\begin{array}{l}\text { Rate of Extermination } \\
(\mathrm{p} 10)\end{array}$ & 0,3157 \\
\hline 11. & Price (p11) & 0,1864 \\
\hline & $\sum$ & 3,652 \\
\hline \multicolumn{2}{|c|}{ Customer Satisfaction Index } & $\mathbf{7 3 , 0 4}$ \\
\hline
\end{tabular}

\section{Conclusion}

According to the result of research about satisfaction of strawberry farmer in utilizing " $\mathrm{X}$ " fungicide, the conclusion of this research can be explained such as:

1. Farmers has known well about fungicide " $\mathrm{X}$ " knowledge such as fungicide type, benefit, procedure, dosage and time. 
However, many farmers don't know at all about using fungicide " $X$ " safely. The majority of farmers have used " $X$ " fungicide in more than 10 years.

2. Factors that affect satisfaction of strawberry farmer in this research are group reference which from family and information source from friend that have a significant effect. It proves that satisfaction can be affected by the factor of social farmer environment and it doesn't only come from the product.

3. The level of satisfaction in utilizing " $X$ " fungicide in the Pandanrejo Village is obtained 0.7304 or $73.04 \%$. It means that strawberry farmers feel satisfied with " $X$ " fungicide according to eleven attributes of the product. Eleven attributes of the product are variety of product size, composition, expire date, procedure, permitte of distribution, product availability, benefit, product information, completeness, rate of extermination and price.

Utilizing an anorganic pesticide must be reduced because Batu City has some programs to use organic matter in the plantation. Because of that, regulator should give some directive about that programe to the farmer in Batu City especially in Pandanrejo Village. Pandanrejo Village has been entered in travel destination for picking fruit in Batu City. Pandanrejo Village can be known further if that village has applied organic agriculture in their strawberry plantation. Therefore, strawberry organic can increase the selling price in the market. But, all of itu must be needed some directive by the regulator and government.

The level of satisfaction in the utilizing anorganic pesticide had high and satisfied. But, there are seldom some research about how high the level of farmer satisfaction in utilizing organic input in plantation. Until then, for the upcoming research can find how satisfied some farmers are in utilizing organic pesticide to control some disease and pest.

\section{References}

Aydogdu, M.H. Yenigun, K. Aydogdu, M. 2015. Factors Affecting Farmers Satisfication From Water User Association in the Harran Plain-GAP Region, Turkey. Journal Agr. Sci. Tech. (2015) Vol. 17:
1669-1684. Harran University, Sanliurfa, Turkey.

Badan Pusat Statistik. 2016. Produksi Tanaman Buah-Buahan Stroberi. https://www.bps.go.id. Diakses pada tanggal 13 Februari 2017.

Engel, J., Blackwell, R., Miniard, P. 1990. Consumer Behavior Sixth Edition. The Driden Press. Orlando.

Hendayana, Rachmat. 2013. Penerapan Metode Regresi Logistik dalam Menganalisis Adopsi Teknologi Pertanian. Informatika Pertanian Vol. 22 No. 1, Juni 2013: 1-9.

Hosmer, D.W. dan Lemeshow, S. 2000. Apllied Logistic Regression, Second Edition. John Willey \& Sons, Inc., Canada. http://resource.heartonline.cn/20150528/1 _3kO QSTg.pdf (Online). Diakses pada 28 Februari 2017

Lemeshow, S., Hosmer Jr, D., W., Klar J., dan Lwanga, S.,K. 1990. Adequacy of Simple Size in Health Studies. World Health Organization.

Luo, W. dan Timothy, D.J. 2016. An Assessmentof Farmer's Satisfaction with Land Consolidation Performance in China. Land Use Policy 61 (2017) 501-510. www.elsevier.com/locate/landusepol. Diakses pada tanggal 13 Maret 2017.

Mustikarini, F., Retnaningsih dan Simanjuntak, M. 2014. Kepuasan dan Loyalitas Petani Padi Terhadap Pestisida. Jurnal Ilmu Keluarga dan Konsumen, Mei 2014, p : 93102 Vol. 7, No. 2 ISSN : 1907 - 6037. Departemen Ilmu Keluarga dan Konsumen, Fakultas Ekologi Manusia. Institut Pertanian Bogor.

Sarmin dan Widajanti E. 2013. Analisis Tingkat Kepuasan Petani Pemakai Air Irigasi Colo Timur Ditinjau dari Kualitas Pelayanan Operasi dan Pemeliharaan Sumber Daya Air Bengawan Solo. Jurnal Ekonomi dan Kewirausahaan Vol. 13, No. 1, April 2013; 14-24.

Sumarwan, Ujang. 2014. Perilaku Konsumen: Teori dan Penerapannya dalam Pemasaran. Ghalia Indonesia. Jakarta. 
Wicaksana, B., Muhaimin, A. and Koestiono, D. (2013) 'Analisis Sikap dan Kepuasan Petani dalam Menggunakan Benih Kentang Bersertifikat (Solanum tuberosum L.) (Kasus di Kecamatan Bumiaji, Kota Batu)', Habitat, 2(3), pp. 184-193. 